\title{
One step ahead, two steps backwards: Energy Transitions and Coal in Developing Countries
}

\author{
Rafia Zaman \\ Business Administration Discipline \\ Khulna University \\ Khulna, Bangladesh \\ rafiazaman12@gmail.com
}

\author{
Christian Hofer \\ Thomas Brudermann \\ Institute of Systems Sciences, Innovation and Sustainability \\ Research, University of Graz \\ Graz, Austria \\ [Christian.Hofer, Thomas.Brudermann]@uni-graz.at
}

\begin{abstract}
Anthropogenic climate change necessitates a transformation of the current fossil-based energy systems towards renewable energies. Despite large agreement on the huge costs of (climate) inaction, several developing countries currently see a massive uptake of carbon-intense coal-based power generation. This study aims to contextualize investment flows for coal projects, with a focus on the Global South. We applied a bipartite network analysis to investigate investment patterns between donor and recipient countries using a secondary database. The results indicate that China, Japan and South Korea are key players in the massive coal extension currently observed in several developing countries of Asia and Africa. While the analysis presented in this paper aids the problem identification and illustration, the lurking grey energy transition will require further research and policy attention.
\end{abstract}

Keywords: Energy transition, sustainable development, renewable energy, coal investment, grey transition.

\section{INTRODUCTION}

Anthropogenic climate change and its unprecedented vulnerabilities necessitate systemic transformations in the existing unsustainable production and consumption structures [1], [2]. A crucial element in such transformation is the sociotechnical reconfigurations of electricity systems towards more sustainable low-carbon sources, in particular renewable energies. Achieving fossil fuel free power sectors by 2100 is an important policy manifesto in the context of the ambitious climate protection goals of the Paris Agreement [3], [4]. In the developed world, progressive attempts to decarbonize energy systems are being made [5] and particularly, coal-based generation is losing its relevance due to falling electricity demand as well as socio-political resistance [3], [6]. BP [7] in its recent outlook projects that renewable energies will exhibit a striking uptake, from $\sim 8 \%$ in 2017 to $\sim 25 \%$ in the 2040 'es global power generation mix. However, a complete substitution of fossil technological trajectories is still debated due to not only current slow progress of renewable energybased system innovations [8]-[10]; an increasing demand for grid-based affordable electricity and on-going industrialization continue to revive coal dependency in the emerging economies of the developing countries [3], [6], [7], [11].

A deeply unsustainable transition, thus, is in the making in several parts (e.g. Asia Pacific, Africa) of the developing world featuring a massive extension of coal-based power generation [6], [12]. At present, $\sim 38 \%$ of global power generation is accredited to coal and it will remain 'fuel-ofchoice' for electricity in the Global South even in 2040 with $\sim 30 \%$ stakes in the fuel mix [7]. In addition, this resurgence is deliberately supported by the governments of the industrializing countries on the moral ground of intense energy insecurity [8], [13]. On the other hand, it is imperative to extensively phase out coal trajectories in order to maintain global climate stability [3]. Recently, a number of (sub)national governments and non-government partners has formed the 'Powering Past Coal Alliance' to accelerate phasing out coal power plants [4]. However, these allied partners merely account for $\sim 3 \%$ of the global coal consumption [14] which in turn might posit a doubt on the prospect of such an initiative. It can, thus, be argued that the dynamics of unsustainable energy transition remain active even in the face of severe climate change impacts.

This 'flipside of energy transition' perspective is still understudied in the sustainable transition literature which largely explore radical innovation-based systemic changes [1], [9]. The transition dynamics of the existing socio-technical system can be explained through destabilization and discontinuation process, and interconnection between geographically distant systems [4], [15], [16]. Although recent transition studies acknowledge the relevance of destabilization or deliberate removal mechanisms to some extent, interrelations between phasing out carbon intense energy technology on the one side, and pushing them to other countries in terms of technology transfer or climate finance, do not receive a systematic attention so far.

This paper attempts to direct attention to such problematic current developments embedded in the electricity system, and to analyze network structures between donor and recipient countries. The aim of the paper is to identify and illustrate 
international money flows for coal projects by the means of a network analysis.

\section{ENERGY TRANSITION LITERATURE}

Sustainable transition frameworks involve deep structural transformations of existing socio-technical systems comprising of technological artefacts, institutions, actor constellations, user practices, norms and regulations, and market structures [17], [18]. The multi-level perspective (MLP), a predominant transition framework [19], analyses transition processes through interactive alignments between and within three analytical levels, niches (radical technologies), socio-technical regimes (institutionalized rules, cognitions, norms) and the exogenous landscape [2], [9], [17]. Long-term systemic changes are captured at the sociotechnical regime as a result of combined top-down landscape pressures and bottom-up niche innovations developments [2], [20]. This quasi-evolutionary transition process reflects a 'systemic fight' between alternative systems (technological niches) and the dominant system (socio-technical regimes) [21]; an alternative system emerges, stabilizes and disrupts the existing regime. However, niche technologies often fail to breakthrough due to techno-institutional path dependencies of the incumbent regimes which create systemic lock-ins [17], [22]. Thus, a low-carbon transition is rather a contested and non-linear process [23] which requires an analysis of issue dynamics [17]; for example, unlocking regimes (e.g. regime destabilization, exnovation) and geographical interconnectivity.

\section{A. Unlocking Regimes}

The loss or abandonment of the old socio-technical system [24] is inevitable in a sustainability transition process and requires the unlocking of core regime components (routines, mindsets, shared beliefs, technical capabilities etc.) [15]. A 'regime destabilization' process [25] is activated when the incumbent system faces increasing external pressures (weakening flow of resources, socio-political delegitimacy) which in turn erodes the internal commitment and strategic responses. This process either opens up (1) 'windows of opportunities' for upscaling innovation processes (early destabilization) or (2) the shift to a new regime (full destabilization) [1], [24]. In the first case, the existing regime does not become obsolete but rather loses its relevance [25] because radical niches and the dominant regime co-exist to perform societal functions [10], [22]. The second case involves a replacement of the old system by the new one. Hence, regime destabilization entails 'creative accumulation' in which incumbents either create new technological competences integrating previous technical know-how or form alliances adopting sustainable technologies [17], [26].

On the other hand, 'exnovation' refers to the purposive destruction or discontinuation of fossil-fuel-based technological trajectories [22], [27]. Exnovation attempts to (i) gradually phase out unsustainable, unwanted socio-technical systems, (ii) deliberately remove physical infrastructure, and (iii) consciously withdraw supportive resources, and deroutinize dominant institutional rationalities associated with the technologies to be eliminated [10], [22], [28]. However, exnovating established trajectories on national levels alone is not sufficient; it is also necessary to consider geographical dimensions (e.g. influence of internationalized actor structure, network flow of resources etc.) in order to materialize a complete energy transition.

\section{B. Geographical Interconnectivity}

The existing transition literature vividly overlooks 'geographies of energy transition', that is, external relationships beyond a national peripheral [16]. Spatial organizations or geographical connections are only metaphorically represented in the MLP; the spatial boundaries between operating levels are defined based on socio-cognitive heuristics: local niches, national socio-technical regimes and international landscape [18], [29]. On the other hand, the global scale in the niche development process is interpreted as an 'epistemic community' which develops generic knowledge from local experiments and shapes immediate innovations [29]. To overcome this 'methodological nationalism', a second generation of MLP or 'multi-scalar MLP' was proposed [30] which aims to capture transition developments in the international contexts alongside national and regional boundaries. Later, [31] proposed the notion of 'global sociotechnical regimes' which outlines dominant institutional logics and structural patterns of a socio-technical system, and disseminates system elements through geographically distant networks. Therefore, the relational perspectives of geography play crucial role in the evolution process of a certain technological trajectory via interconnected flows of resources [32].

\section{METHOD}

The data source for the performed analysis was the NRDC (Natural Resources Defense Council) Consolidated Coal and Renewable Energy Database of 2017 [33]. This database contains comprehensive data on international investments for coal and renewable energy projects by G20 public financing institutions announced between January 2013 and August 2017. The coal-related data in this database includes information on coal power plants, mining, transport, and transmission and distribution projects. The database [33] is a compilation from various sources, including a number of energy-related databases and institutional reports. Besides, non-government sources and news articles have been used for financial estimations in case of lack of availability or full disclosure of data for countries like China, Germany and South Korea. Hence, data might not entirely be accurate in few cases despite its comprehensive coverage; there also could be additional projects which are not included in the NRDC database [33]. Based on the secondary data available in this database, we filtered coal projects related to power plants and applied a network analysis. A bipartite graph was derived from the investment data, with two types of nodes: donors and recipients. Two different analyses were run for projects in Asia and Africa/Middle-East.

The bipartite graphs are presented as follows: The sizes of the nodes are depending on the investment volume flowing in (in recipient countries) or flowing out (in donor countries). Volumes below a certain threshold (i.e. 1 billion US\$ in the Asia graph, 275 million US\$ in the Africa graph) are represented as equally small nodes; larger volumes are 
represented by proportionally bigger nodes. The strengths of the nodes, connected by edges, indicate the number of projects between two nodes.

For the derived bipartite graphs we calculated standard network parameters, i.e. degree centrality and clustering coefficient for each node. The degree centrality, denoted by $d^{*}{ }_{i}$, indicates which donor countries $\left(V_{l}\right)$ have a central role in the network in terms of investment flow in the receiving countries $\left(V_{2}\right)$. Using the maximum possible values of node strengths $\left(n_{1}\right.$ or $\left.n_{2}\right)$ normalized degree centrality measures were calculated based on the equations (1) and (2), as stated in [34].

$$
\begin{array}{r}
d_{i}^{*}=\frac{d_{i}}{n_{2}} ; i \in V_{1} \\
d_{j}^{*}=\frac{d_{j}}{n_{1}} ; j \in V_{2}
\end{array}
$$

The clustering coefficient, denoted by $c c$. $(u)$ was calculated using equations (3) and (4), as stated in [35]. The local density measure, $c c .(u, v)$ captures the correlation between two nodes; it indicates the extent to which a donor country $(u)$ invests into a country $(v)$, which is also receiving funds from the donor's neighbor country $(N)$. It ranges from 0 to $1: c c .(u, v)=0$ indicates different receiving countries in the cluster, while $c c .(u, v)=1$ resembles similar recipient countries.

$$
\begin{gathered}
\sum_{v \in N(N(u))} c c \cdot(u, v) \\
|N(N(u))| \\
c c .(u, v)=\frac{|N(u) \cap N(v)|}{|N(u) \cup N(v)|}
\end{gathered}
$$

\section{RESULTS}

\section{A. Coal projects in Asia}

Table I represents the bipartite network analysis of foreign investments into upcoming coal projects in Asia. The results indicate that three Asian countries, i.e. China, Japan, and South Korea, are the major donors representing 93\% of total coal project investments. In terms of recipients, Indonesia, Vietnam, and Bangladesh account for $83 \%$ of investment inflows. In addition, the bipartite network graph of Asian coal investments is visualized in Fig. 1.

TABLE I. LEADING COAL INVESTORS IN ASIA

\begin{tabular}{|l|c|c|r|r|r|}
\hline \multirow{3}{*}{ Donors } & \multicolumn{3}{|c|}{ Investments } & \multicolumn{2}{c|}{ Network } \\
\cline { 2 - 6 } & $\begin{array}{c}\text { Project } \\
\text { volume } \\
\text { (mio. } \\
\text { US\$) }\end{array}$ & $\begin{array}{c}\text { Number } \\
\text { of } \\
\text { projects }\end{array}$ & $\begin{array}{c}\text { Number of } \\
\text { receiving } \\
\text { countries }\end{array}$ & $\begin{array}{c}\text { Degree } \\
\text { centrality }\end{array}$ & $\begin{array}{c}\text { Clustering } \\
\text { coefficient }\end{array}$ \\
\hline China & $20,217.3$ & 55 & 11 & 0.733 & 0.202 \\
\hline
\end{tabular}

\begin{tabular}{|l|r|r|r|r|r|}
\hline \multirow{2}{*}{ Donors } & \multicolumn{3}{|c|}{ Investments } & \multicolumn{2}{c|}{ Network } \\
\cline { 2 - 6 } & $\begin{array}{c}\text { Project } \\
\text { volume } \\
\text { (mio. } \\
\text { US\$) }\end{array}$ & $\begin{array}{c}\text { Number } \\
\text { of } \\
\text { projects }\end{array}$ & $\begin{array}{c}\text { Number of } \\
\text { receiving } \\
\text { countries }\end{array}$ & $\begin{array}{c}\text { Degree } \\
\text { centrality }\end{array}$ & $\begin{array}{c}\text { Clustering } \\
\text { coefficient }\end{array}$ \\
\hline Japan & $16,895.8$ & 43 & 7 & 0.467 & 0.295 \\
\hline $\begin{array}{l}\text { South } \\
\text { Korea }\end{array}$ & $4,670.3$ & 21 & 5 & 0.333 & 0.321 \\
\hline India & $1,600.0$ & 2 & 2 & 0.133 & 0.450 \\
\hline ADB & $1,050.5$ & 2 & 2 & 0.133 & 0.278 \\
\hline Germany & 335.7 & 7 & 4 & 0.267 & 0.205 \\
\hline $\begin{array}{l}\text { World } \\
\text { Bank }\end{array}$ & 147.0 & 1 & 1 & 0.067 & 0.000 \\
\hline Russia & 20.0 & 2 & 2 & 0.133 & 0.341 \\
\hline Italy & 0.0 & 1 & 1 & 0.067 & 0.322 \\
\hline US & 0.0 & 2 & 2 & 0.133 & 0.450 \\
\hline
\end{tabular}

The measure of degree centrality reveals that China $\left[d^{*}=\right.$ 0.73] plays a central role in accelerating coal power investments across Asia. The total investment size in 55 coal projects announced is about $\sim 20$ billion US\$ which tend to flow into eleven Asian countries. Japan $\left[d^{*}=0.47\right]$ and South Korea $\left[d^{*}=0.33\right]$ are also actively participating in total 64 Asian coal projects with investment volume of $\sim 17$ and $\sim 5$ billion US\$, respectively. On the other hand, Germany $\left[d^{*}=\right.$ 0.27] and India, Russia, USA along with $\mathrm{ADB}\left[d^{*}{ }_{i}=0.133\right]$ have relatively lower contributions with a combined total investment of $\sim 3$ billion US\$ which is less than a quarter (i.e. $20 \%$ ) of Chinese investments. Apart from that, World Bank $\left[d^{*}=0.07\right]$ is committed to one coal project only with substantially large investment size ( $\sim 0.1$ billion US\$).

In terms of clustering coefficient, India and US [cc. $(u)=$ 0.45] have relatively higher clustering in terms of financing coal projects in Asia. Recipients of their outward investment partially overlap, that is, investments are mainly centered to Vietnamese and Bangladeshi coal power plants. With slightly less clustering, Russia [cc. $(u)=0.34]$, Italy $[c c .(u)=0.32]$ and South Korea $[c c .(u)=0.32]$ also have common recipients, including Vietnam, Indonesia and Mongolia. On the other hand, China $[c c .(u)=0.20]$ has less local density indicating a diversified investment portfolio for coal projects. Chinese investment flows tend to mobilize into a number of countries across South Asia (e.g., Bangladesh, Pakistan, Myanmar), Southeast Asia (e.g., Vietnam, Indonesia, Cambodia), and Central Asia and Caucasus (e.g., Mongolia, Tajikistan, Uzbekistan, Georgia).

\section{B. Coal projects in Africa and Middle-East}

Table II represents the bipartite network analysis of foreign investments into upcoming coal projects in Africa and Middle-East. Interestingly, this picture looks rather as similar as Asian case, at least with regards to the main donors - which again are China, Japan and South Korea accounting for $94 \%$ of outward investment. The major recipients are Zimbabwe, Morocco, and South Africa constituting about $73 \%$ of those investment flows. The bipartite network graph of African and Middle-East coal investments is presented in Fig. 2. 
TABLE II. LEADING COAL INVESTORS IN AFRICA AND MIDDLE-EAST

\begin{tabular}{|l|r|r|r|r|r|}
\hline \multirow{2}{*}{ Donors } & \multicolumn{3}{|c|}{ Investments } & \multicolumn{2}{c|}{ Network } \\
\cline { 2 - 6 } & $\begin{array}{c}\text { Project } \\
\text { volume } \\
\text { (mio. } \\
\text { US\$) }\end{array}$ & $\begin{array}{c}\text { Number } \\
\text { of } \\
\text { projects }\end{array}$ & $\begin{array}{c}\text { Number of } \\
\text { receiving } \\
\text { countries }\end{array}$ & $\begin{array}{c}\text { Degree } \\
\text { centrality }\end{array}$ & $\begin{array}{l}\text { Clustering } \\
\text { coefficient }\end{array}$ \\
\hline China & $6,602.8$ & 27 & 11 & 0.688 & 0.129 \\
\hline Japan & $1,790.3$ & 7 & 3 & 0.188 & 0.333 \\
\hline $\begin{array}{l}\text { South } \\
\text { Korea }\end{array}$ & 754.0 & 4 & 3 & 0.188 & 0.292 \\
\hline $\begin{array}{l}\text { South } \\
\text { Africa }\end{array}$ & 150.0 & 2 & 1 & 0.063 & 0.091 \\
\hline Germany & 141.5 & 2 & 2 & 0.125 & 0.083 \\
\hline India & 112.0 & 4 & 2 & 0.125 & 0.255 \\
\hline AfDB & 100.0 & 2 & 2 & 0.125 & 0.222 \\
\hline $\begin{array}{l}\text { World } \\
\text { Bank }\end{array}$ & 40.8 & 2 & 2 & 0.125 & 0.000 \\
\hline
\end{tabular}

With regards to degree centrality, China $\left[d^{*}=0.68\right]$ again takes the lead in mobilizing funds for coal power investments in these continents. With investment volume of $\sim 6.6$ billion US\$, China is committed to upcoming 27 coal projects of eleven countries. Japan and South Korea $\left[d^{*}{ }_{i}=0.19\right]$ have relatively moderate contributions in total eleven projects; however, Japan's investment ( $\sim 1.8$ billion US\$) is more than double of South Korea's volume ( $\sim 0.8$ billion US\$). On the other hand, Germany, India, and multilateral donor banks $\left[d^{*}=0.13\right]$ contribute almost equally both in terms of investment size and number of coal projects. Their combined investments ( 0.4 billion US\$) is, however, less than $10 \%$ of Chinese investment volume. Surprisingly, South Africa $\left[d^{*}{ }_{i}=\right.$ 0.06 ] is listed for single country investments portfolio of 0.2 billion US\$ which is slightly higher than the latter donor groups.

With regards to clustering coefficient, Japan $[c c .(u)=0.33]$ and South Korea $[c c .(u)=0.29]$ both have almost similar recipient groups, including Egypt and Botswana. Besides, India $[c c .(u)=0.26]$ and African Development Bank (AfDB) $[c c .(u)=0.22]$ both invest in Mozambique regardless of their different recipient groups, e.g., Zimbabwe and Kenya. On the other hand, the coefficient for China $[c c .(u)=0.13]$ is relatively low with a diverse outward investment into a number of countries in Sub-Sharan Africa, North Africa, and Middle-East. Similarly, South Africa $[c c .(u)=0.09]$, Germany $[c c .(u)=0.08]$, and World Bank $[c c .(u)=0.0]$ seem to rarely invest in the countries in which the other donors exhibit substantial investment contribution. Their appearance is visible in countries like Zambia, Israel and Senegal.

The above findings, as presented in Table I and Table II, indicate that the Asian financial banks and institutions from China, Japan, and South Korea clearly dominate investment flows to the coal power plants in Asia, Africa and MiddleEast, while investment is substantially squeezed from the developed world, e.g. USA, Russia, EU countries and other multilateral donor banks. In addition, foreign investments are highly concentrated into Asian coal projects compared to Middle-East and Africa - possibly due to the fact that six out of the next eleven (N-11) emerging economies are located in South Asia (Bangladesh, Pakistan), Southeast Asia (Vietnam, Indonesia, and Philippines), and East Asia (South Korea).

\section{CONCLUSIONS}

Investment in upcoming coal power plants can always be argued in the context of improving energy security and reducing energy poverty in the Global South. As the network analysis presented in this paper confirms, China, Japan and South Korea have become the frontrunners in transferring the required investments and technologies to low and middleincome countries in Asia and Africa, which at the moment hardly contribute to global greenhouse gas emissions. While easily justifiable from the perspectives of energy security and energy poverty, such massive scale investments may destabilize renewable trajectories, increase resource dependencies and induce environmental problems in the affected countries; additionally such a 'grey transition' momentum jeopardizes global climate change mitigation targets.

Energy service security in several developing countries at the moment comes at the expense of environmental externalities associated with the renaissance of coal power fleets. Proponents even claim for a catalytic role of advanced coal technology as a solver in the climate agreement; these claims however are questionable. On the other hand, there are voices that demand carbon-constrained development pathways for developing countries. These claims clearly raise questions of climate and energy justice.

Despite its simplicity and limitations, the analysis presented in this paper may aid the problem definition and illustration of ongoing problematic developments in the energy sector. The underlying mechanisms of a lurking grey energy transition in parts of the developing world, as well as possible counter-strategies on national and international levels will definitely require further attention by academic researchers and policy makers. 


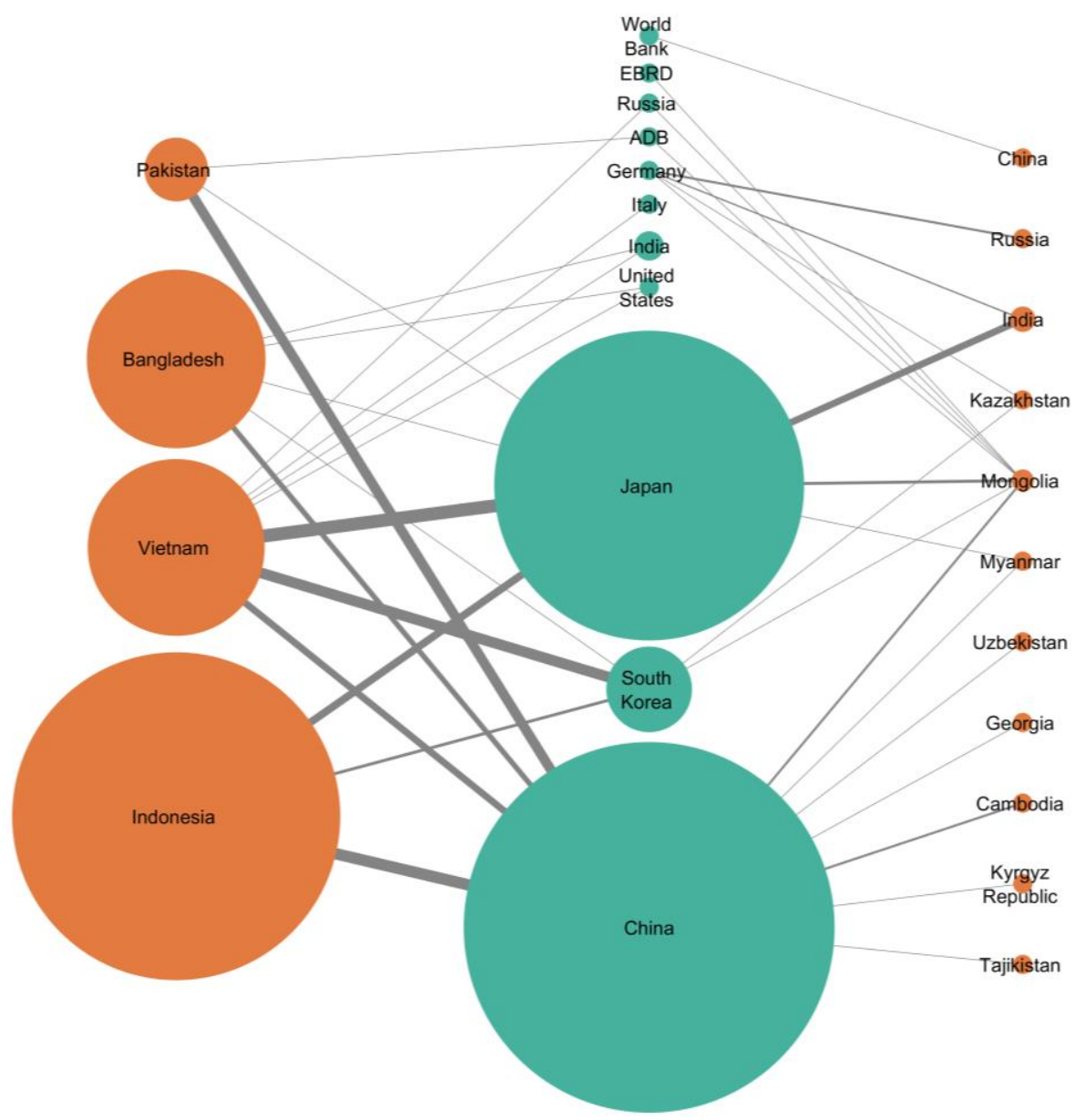

Figure 1. Bipartite network graph for coal investments in Asian countries.

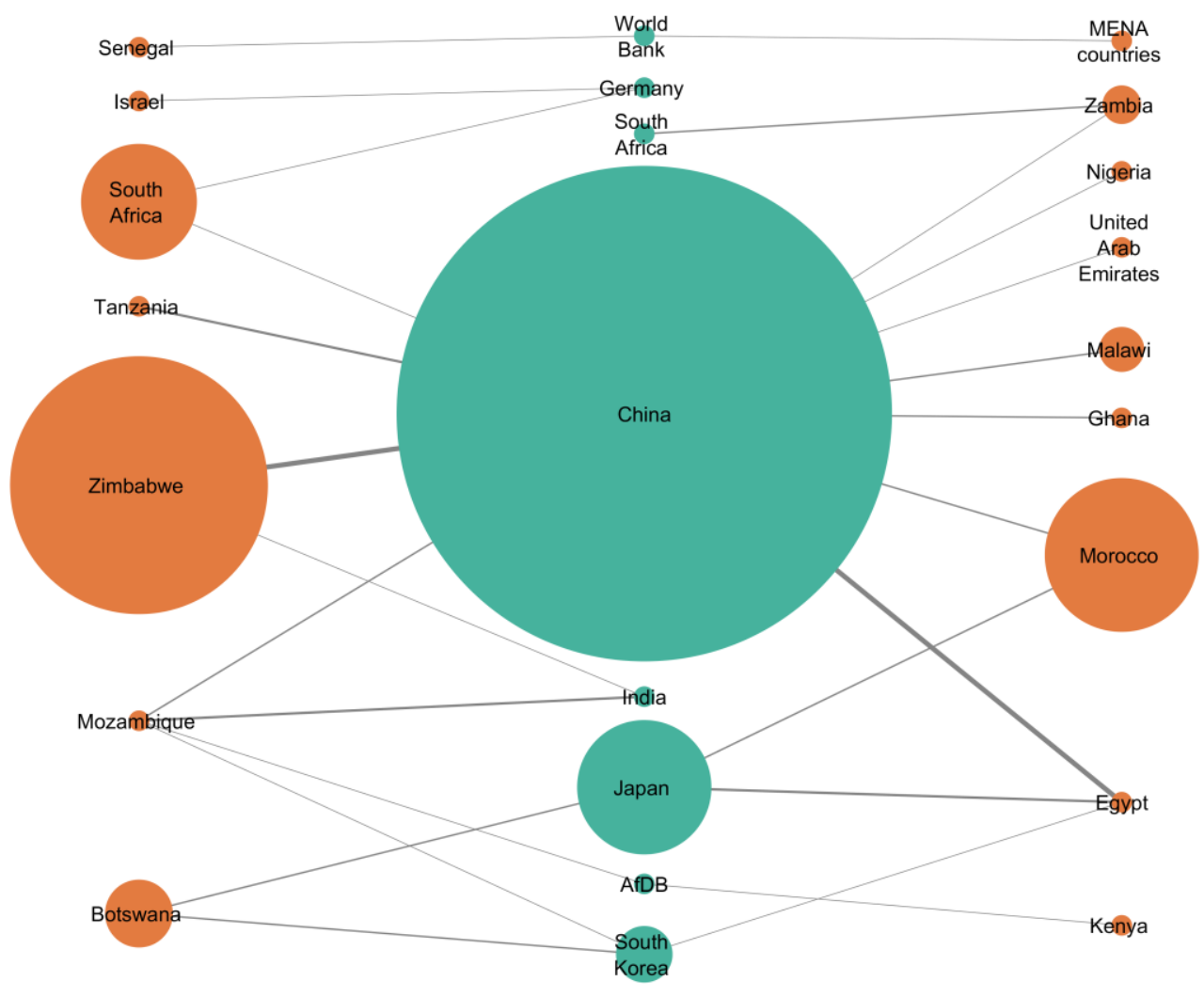

Figure 2. Bipartite network graph for coal investments in African and middle-east countries. 


\section{REFERENCES}

[1] A. Kuokkanen, A. Nurmi, M. Mikkilä, M. Kuisma, H. Kahiluoto, and L. Linnanen, "Agency in regime destabilization through the selection environment: The Finnish food system's sustainability transition," Res. Policy, vol. 47, no. 8, pp. 1513-1522, 2018.

[2] P. Kivimaa and F. Kern, "Creative destruction or mere niche support? Innovation policy mixes for sustainability transitions," Res. Policy, vol. 45, no. 1, pp. 205-217, 2016.

[3] J. Goodman, J. P. Marshall, and R. Pearse, "Coal, climate and development: Comparative perspectives," Energy Policy, vol. 99, pp. 180-183, 2016.

[4] K. S. Rogge and P. Johnstone, "Exploring the role of phase-out policies for low-carbon energy transitions: The case of the German Energiewende," Energy Res. Soc. Sci., vol. 33, pp. 128137, 2017.

[5] R. Zaman, T. Brudermann, S. Kumar, and N. Islam, "A multicriteria analysis of coal-based power generation in Bangladesh," Energy Policy, vol. 116, pp. 182-192, 2018.

[6] C. Brognaux, E. Boudier, T. Möncks, and M. Gerecs, "Why Coal Will Keep Burning," BCG Henderson Institute (March Issue), The Boston Consulting Group, 2018. Available: https://www.bcg.com/publications/2018/why-coal-will-keepburning.aspx

[7] BP, "BP Energy Outlook," Energy Economics: 2018 Edition, BP p.1.c.:UK, 2018. Available: https://www.bp.com/content/dam/bp/en/corporate/pdf/energyeconomics/energy-outlook/bp-energy-outlook-2018.pdf

[8] C. Roberts et al., "The politics of accelerating low-carbon transitions: Towards a new research agenda," Energy Res. Soc. Sci., vol. 44, pp. 304-311, 2018.

[9] A. Leipprand and C. Flachsland, "Regime destabilization in energy transitions: The German debate on the future of coal," Energy Res. Soc. Sci., vol. 40, pp. 190-204, 2018.

[10] M. David, "The role of organized publics in articulating the exnovation of fossil-fuel technologies for intra- and intergenerational energy justice in energy transitions," Appl. Energy, vol. 228, pp. 339-350, 2018.

[11] WCA, "Energy Equation ASEAN's Energy: The roel of low emission coal in deriving sustainable energy future," ASEAN Centre for Energy, World Coal Association (WCA): Indonesia, 2017.

[12] C. Shearer, N. Mathew-Shah, L. Myllyvirta, A. Yu, and T. Nace, "Boom and Bust 2018: Tracking the global coal plant pipeline," The Global Coal Plant Tracker; 2018. Available: https://endcoal.org/wpcontent/uploads/2018/03/BoomAndBust_2018_r4.pdf

[13] R. Zaman and T. Brudermann, "Energy governance in the context of energy service security: A qualitative assessment of the electricity system in Bangladesh," Appl. Energy, vol. 223, pp. 443-456, 2018.

[14] G. Corsi, "COP23 : A Critical Assessment of the Conference's Outcomes," A Climate Institute Publication: Washington DC, 2018. Available: http://climate.org/wpcontent/uploads/2018/01/Corsi-COP23.pdf

[15] G. Kungl and F. W. Geels, "Sequence and alignment of external pressures in industry destabilisation: Understanding the downfall of incumbent utilities in the German energy transition (19982015)," Environ. Innov. Soc. Transitions, vol. 26, pp. 78-100, 2018.

[16] G. Bridge, S. Bouzarovski, M. Bradshaw, and N. Eyre, "Geographies of energy transition: Space, place and the lowcarbon economy," Energy Policy, vol. 53, pp. 331-340, 2013.

[17] F. W. Geels, "Disruption and low-carbon system transformation: Progress and new challenges in socio-technical transitions research and the Multi-Level Perspective," Energy Res. Soc. Sci., vol. 37, pp. 224-231, 2018.

[18] J. Markard, R. Raven, and B. Truffer, "Sustainability transitions: An emerging field of research and its prospects," Res. Policy, vol. 41, no. 6, pp. 955-967, 2012.

[19] S. Sorrell, "Explaining sociotechnical transitions: A critical realist perspective," Res. Policy, vol. 47, no. 7, pp. 1267-1282,
2018.

[20] U. Jørgensen, "Mapping and navigating transitions - The multilevel perspective compared with arenas of development," Res. Policy, vol. 41, no. 6, pp. 996-1010, 2012.

[21] F. J. de Haan and J. Rotmans, "A proposed theoretical framework for actors in transformative change," Technol. Forecast. Soc. Change, vol. 128, pp. 275-286, 2018.

[22] M. David, "Moving beyond the heuristic of creative destruction: Targeting exnovation with policy mixes for energy transitions," Energy Res. Soc. Sci., vol. 33, pp. 138-146, 2017.

[23] F. W. Geels, B. K. Sovacool, T. Schwanen, and S. Sorrell, "The Socio-Technical Dynamics of Low-Carbon Transitions," Joule, vol. 1, no. 3, pp. 463-479, 2017.

[24] B. Turnheim and F. W. Geels, "The destabilisation of existing regimes: Confronting a multi-dimensional framework with a case study of the British coal industry (1913-1967)," Res. Policy, vol. 42, no. 10, pp. 1749-1767, 2013.

[25] B. Turnheim and F. W. Geels, "Regime destabilisation as the flipside of energy transitions: Lessons from the history of the British coal industry (1913-1997)," Energy Policy, vol. 50, pp. 35-49, 2012.

[26] A. Bergek, C. Berggren, T. Magnusson, and M. Hobday, "Technological discontinuities and the challenge for incumbent firms: Destruction, disruption or creative accumulation?," Res. Policy, vol. 42, no. 6-7, pp. 1210-1224, 2013.

[27] D. A. Heyen, L. Hermwille, and T. Wehnert, "Out of the comfort zone! Governing the exnovation of unsustainable technologies and practices," Gaia, vol. 26, no. 4, pp. 326-331, 2017.

[28] L. Hermwille, "En Route to a Just Global Energy Transformation? The Formative Power of the SDGs and the Paris Agreement," Wuppertal Institute for Climate, Environment and Energy: Germany, 2017. Available: http://library.fes.de/pdffiles/iez/13453.pdf

[29] L. Coenen, P. Benneworth, and B. Truffer, "Toward a spatial perspective on sustainability transitions," Res. Policy, vol. 41, no. 6, pp. 968-979, 2012.

[30] R. Ravena, J. Schota, and F. Berkhoutb, "Space and scale in socio-Technical transitions," Environ. Innov. Soc. Transitions, vol. 4, pp. 63-78, 2012.

[31] L. Fuenfschilling and C. Binz, "Global socio-technical regimes," Res. Policy, vol. 47, no. 4, pp. 735-749, 2018.

[32] T. Hansen and L. Coenen, "The Geography of Sustainability Transitions: Review, Synthesis and Reflections on an Emergent Research Field The Geography of Sustainability Transitions: Review, Synthesis and Reflections on an Emergent," vol. 17, pp. 92-109, 2015.

[33] C. Han and S. Jack, "Power Shift: Shifting G20 international public finance from coal to renewables," Report No. 17-10-B, Washington, D.C., 2017.

[34] S. P. Borgatti and D. S. Halgin, "Analyzing Affiliation Networks," in The SAGE Handbook of Social Network Analysis, J. Scott and P. J. Carrington, Eds. SAGE Publications Ltd., London, 2014, pp. 417-433.

[35] M. Latapy, C. Magnien, and N. Del Vecchio, "Basic notions for the analysis of large two-mode networks," Soc. Networks, vol. 30, no. 1, pp. 31-48, 2008. 